\title{
DE DE GRUYTER OPEN

\section{THE INTERFERENCE OF ABANDONED MINING SITES WITH THE SURROUNDING HUMAN COMMUNITIES}

\section{Ionce Anca ${ }^{1}$, Ionce Ruxandra ${ }^{2}$}

Keywords: abandoned mining sites, health risks, social responsability

\begin{abstract}
The social, economic and environmental effects of the mining activities on the surrounding human communities, specifically after the cessation of such profile units without undertaking the necessary safety and greening measures, are rarely analysed in our country.

The modifications in quality and capacity of economic use of the abandoned mining perimeters after the cessation of activity, corroborated with the pressure exercised by the citizens to re-establish the ownership rights, with the impact on the general state of health and security of the local population, are only some of the forms of social impact these areas have.

In the Suceava County there are over 15 abandoned mining sites in populated areas.

The present paper will address these issues in critical areas in the Suceava County and will present the forms of risk these areas pose on the health and safety of the surrounding human communities, most of which are due to the lack of measures meant to reduce the ecological impact of the mining sites after their abandonment.
\end{abstract}

The social effects of bench or ore mining have always been less understood, and are often unknown not only to mining companies, but also to the specialized authorities. Ore deposits and the necessary mineral preparation units are usually located on public, private or shared land used for other activities or purposes or on land with potential ecological importance.

According to the World Investment Report, 2007- Transnational Corporation Extractive Industries and Development, UNCTA, the possible forms of social impact mining activities have can be classified as followed:

${ }^{1}$ EPA Suceava, anca.ionce@gmail.com

${ }^{2}$ EUDEMOS Association, eudemos.ro@gmail.com 
$\checkmark$ impact on the health and safety of the workers or upon the nearby communities;

$\checkmark$ endangering or affecting the culture, traditional life style and social welfare of the local population;

$\checkmark$ destabilization of internal power relations and affecting the traditional social structures;

$\checkmark$ conflicts regarding the management and use of local lands;

$\checkmark$ possible tensions between the local communities and immigrant workers, that can lead to a reconfiguration of the social structures or of the local relations and identities;

$\checkmark$ the influx of migrant workers, contractors and other entities that are engaged in large-scale mining projects can affect the social structure of the local population and also can cause metabolic diseases such as: increasing the level of alcohol abuse, gambling, violence and crime together with an increased rate of illnesses.

In the Suceava County, areas where mining activities were conducted, a mono-industrial development occurred. For this reason, an unwanted ecological impact can be added to the list of negative social impacts. This is applicable to all other areas in the country where such activities have been or still are being conducted.

If necessary environmental protection and/or safety measures are too tardiveif not at all undertaken- the ecological imbalance caused by mining activities will not only be enhanced in time, but also new problems will start to appear, especially of social and economic in nature regarding the re-integration of the redundant personnel into the workforce.

At the present time, numerous subsequent studies have been made regarding the impact caused by bench and ore mining on environmental factors. These studies focused on ecological accidents and were initiated as a consequence of the ecological disaster that occurred in the year 2000, when after abundant rainfall during the night of $30^{\text {th }}$ of January, a volume of over 1000 cubic meters containing sterile material originating from the Bozânta Mare decantation pond belonging to SC AURUL SA Baia Mare contaminated the Lăpuș River with cyanide; this led to the contamination of the hydrographic network downstream of the rivers Somes, Tisa and the Danube as well as the aquifer along the Lăpuş alluviums. Thiese studies aimed to evaluate the effects cyanide pollution had on the watercourses affected by the accident. 


\section{Case study: Ostra village, Suceava County}

The intensive mining activity practiced in Ostra was focused on two areas:

$>$ one activity focused on geological exploration and exploitation of sulphides complex, copper sulphides and barite;

$>$ Activity regarding the mining preparations of the complex ore and barite.

\section{A brief history of the mining activity in the Ostra}

The prospecting and exploitation works regarding the copper and barite ore in the proximity of the Ostra village have been conducted between 1953 and 1965. Exploitation of the copper layer from from Leșu Ursului started in the second semester of 1965 and lasted until December 2005 when the unit was permanently closed. Barite exploitation lasted between 1968 and 2003. The exploration/exploitation perimeteres in Ostra were as followed:

- complex ore exploration: the mining perimeter Alunișul Mare - Alunișul Mic, mining perimeter 24 Puzdra

- barite exploitation: the mining perimeter Alunis - Clife, the mining perimeter Ostra - Greben, the mining perimeter Aluniș - Clife and the Ostra quarry.

Above the mining perimeter Alunişul Mare-Alunișul Mic there is mining tunnel containing sterile deposit resulted from research on uranium mineralization.

The preparation plant opened in 1965 having three grinding-flotation lines. Within the plant, there were two distinct lines: one for the copper ore and the other for the impregnated copper ore. The floatation lines for copper ore functioned until 2007, when the activity ceased.

The barite floatation was commenced in 1968 as a result of ore preparation from the Ostra quarry and subterranean mining in Aluniș- Greben and Holdița. Starting with 1985, the ore assortment from the Ostra quarry started to decrease almost until extinction, so that in 2003 the activity of non-metallic ore preparation ceased.

As a consequence of mining activities, the main polluting factors are the tailing dumps resulting from mining exploration/exploitation, tailings ponds resulting from mining preparation of complex ore and barite, pyrite and zinc concentrate deposits along the Brăteasa stream and on site installations belonging to the Tarniţa Preparation Plant.

- Tailing dumps belonging to the mining perimeters for exploration/exploitation on the territory of the Ostra village spread over aprox. 20 hectars, having a total volume of $2,744,000$ cubic meters. The terrain occupied by the dump was initially used for forestry. The contruction technique for dumps as well as the geomorphology of the land area were such that the dump was not to be uncovered, meaning that the sterile material was being deposited directly on the emplacement after the deforestation. 
- The Ostra quarry pit shows a remnant terraced gap on the valley of the Ariniş stream, the rock which forms the basis being uncovered so that the fragmentation, decay and alteration (some of the barium compounds are highly toxic) contributed to the degradation of the area.

- Tailing ponds used for the Preparation Unit Tarnița.

Tailing ponds are a result of the complex activities conducted by the use of mining mass preparation installations, with the purpose to mechanically decontaminate the residual waters and to deposit for an unlimited period of time the sterile resulted from the ore preparation.

At the Tarnita preparation plant, the sterile from both the non-ferrous and barite sectors is being stored in four tailings ponds: the Old Gate, Ostra, Tărnicioara and Valea Străjii. The surface covered by these tailing ponds is 80.63 hectars and the total volume is of $12,026,500$ cubic meters.

The vast majority of the ore resulted from the flotation of non-ferrous and copper ores consists of sericite quartz, chlorite shale, chlorite-sericite and pyrite shale with a certain content of $\mathrm{Cu}, \mathrm{Pb}, \mathrm{Zn}, \mathrm{BaSO}$.

Since 1996, the pyrite resulted from the copper ore separation process has been deposited in the tailing ponds, leading to an accentuated seepages with a high content of iron oxides.

\section{How the quality of community life in Ostra is currently affected}

Mining is a high impact activity with effects on the natural environment and human communities and with sometimes irreversible consequences on the quality of water, soil, terrestrial and aquatic ecosystems. Another important risk is the degradation of air quality with immediate and long term repercussions on the health of the local population.

In Ostra, people's quality of life is determined by the interdependence between the mining activity and the preparation installations and geographical, climatic and hydrographic factors. Ostra is situated downstream of the mining site, on the valley line of the Brăteasa stream, approx. $0.5 \mathrm{~km}$ away from the tailings deposit Ostra A, B, C. In the mining area there is also a forestry area with several facilities used by shepherds.

The influence of climatic conditions:

In a study conducted by D. Mihăilă, V. Budui, I. Al. Cristea, I, Tănasă from the "Ştefan cel Mare" University of Suceava, focued on the elaboration of a climatic risk map in the Suceava County, the sollowing is stated:

"The Suceava County, being situated at the contact point of two climatic sectors with ample vertical landscape development, presents a remarkable variety of climatic manifestations. Temporal and spatial climatic contrasts are being accentuated by a highly active atmospheric dynamic and by the intervention of the 
geographic and human environment, both which having profoundly modified the characteristics of the active surface in the past century "(2006, Annals of" Ştefan cel Mare "University of Suceava, page 75).

Climatic and meteorological risk phenomena in recent years have also strongly affected stability of the Tărnicioara tailing ponds (in the years: 2002, 2005, 2006, 2007, 2008, 2012, 2016, 2017), Poarta Veche (2003, 2005, 2017). This happened by abundant precipitation, as a result of which large sterile masses were transported into surface waters; in 2006, the evacuation of the population from the community of Ostra was imminent, especially for the locals who had their homes along the Brăteasa stream.

In regards to the air dynamics responsible for the emission, propagation and dispersion of atmospheric toxicity at the Tarniţa Preparation Plant, it is to be noted that the area is characterized by a high frequency of mountain air circulation, leading to daytime pollution in the upstream and downstream areas.

The influence of surface and underground waters:

In regards to the geographical positioning of the Ostra - Tarniţa mining site, the magnitude of the river basins in the area also plays an important role in impact amplitude mining activities exert on the environmental factor "water".The hydrographic network is well represented by water courses with flows ranging from $20-60 \mathrm{~m} 3 / \mathrm{s}$. The receiver for all contaminated water discharges is the Brăteasa stream, both directly and indirectly through its tributaries (Scăldători stream, Tărnicioara stream, Pietrii stream, Valea Străjii stream etc.) and numerousother springs that come in contact with landfill or plant facilities. Such springs have also been identified: four along the Tărnicioara decantation pond area, five in the Poarta Veche tailing pond, three along the Valea Străjii tailing pond and another one crossing through the polymetal ore flotation section.

The impact evaluation of mining activities in the Ostra area on the human communities is a difficult process, considering the lack of a comprehensive legislation specifically addressing this sector.

The people of the Ostra village who owned land in the area of the mining sites have been enclosing their properties- as in the case of the decantation pool Ostra A, $\mathrm{B}, \mathrm{C}$ - in order to tend for their flocks. Since the mining operator does not exist, some areas pertaining to the mining site that contain mining equipment are being sporadically monitored, specifically the areas where ecological rehabilitation activities are being conducted such as in the decantation pools Tărnicioara and Valea Străjii.

The Brăteasa stream that flows through Ostra is an important water source for domestic animals and for local agriculture. The quality of the food consumed by the locals depends considerably on the water quality of the stream. As a consequence, the lack of or the postponing of measures to stop the pollution 
sources from affecting the stream will have immediate effects on the health of the local population.

Other problems concerning the mining site are the possibilitiy of blocking the flow section of the Brăteasa stream - which, as mentioned above, flows centrally through Ostra- by the tailing pond of the Ostra quarry and the local hydrology: the precipitation water flows gravitationally down the quarry slopes and accumulates in the pit bottom where it is evacuated into the Ariniș and Brăteasa streams. In the open pit of the Ostra quarry Southern Sector, the accumulated waters' parameters (heavy metals, sulphates, iron, calcium, manganese) reach values beyond the maximum allowable concentration and an acid $\mathrm{pH}(3,5)$. This situation led to the decision to start specific ecologizing activities such as ramping up the quarry's pit, arranging an anaerobic bog over a surface of 0,75 ha; none of the activities has been yet initiated.

For the area designated to mining processing, the following aspects need to be mentioned:

- In 2012, the land surface associated with the flotation equipment for polymetallic ore and barite on both banks of the Brăteasa stream, the concentrate deposits and the micro-pools situated on the right bank of the Brăteasa stream have all been bought by privat companies. After a rather chaotic decommissioning of buildings and ore preparation units- mostly done in order to recover scrap metalthe area was abandoned, since the economic operator was not able to intabulate the property. The tailing leakage and ore concentrates on these platforms constitute a continuous source of pollution of the Brăteasa stream.

- The positioning of the tailing deposits (either along the water streams, as in the case of the tailing ponds Tărnicioara and Valea Străjii, or in the close proximity of water streams, such as the tailing ponds Ostra and Poarta Veche) is a cause for both real and potential pollution of surface and underground waters. One of the main massive pollution causes of surface and underground waters in Ostra are the tailing ponds resulted from technological accidents due to unfinished or lack of safety measures. A destabilization of a tailing pond could lead to direct, unstoppable spills into the water course.

- Next to the spills of tailing masses into the water streams, active seepages occur, the so-called acid rock drainage phenomenon, loaded with iron oxides and heavy metals from the banks of the tailing ponds Poarta Veche, Tărnicioara and Valea Straja. 


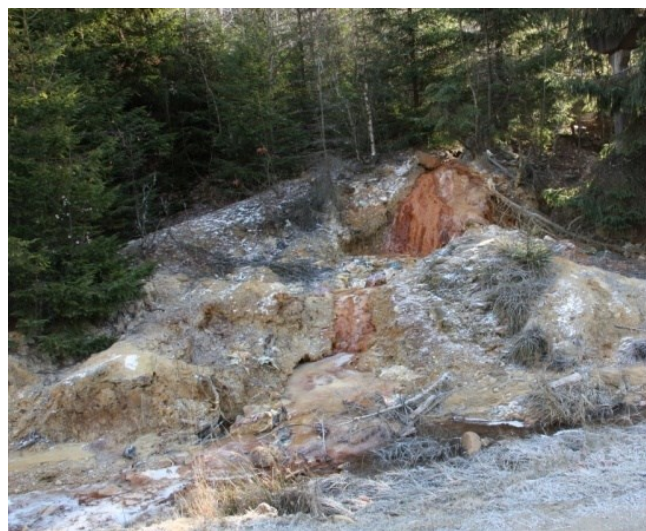

Fig.1. Acid drainage - Tailing pond Poarta Veche

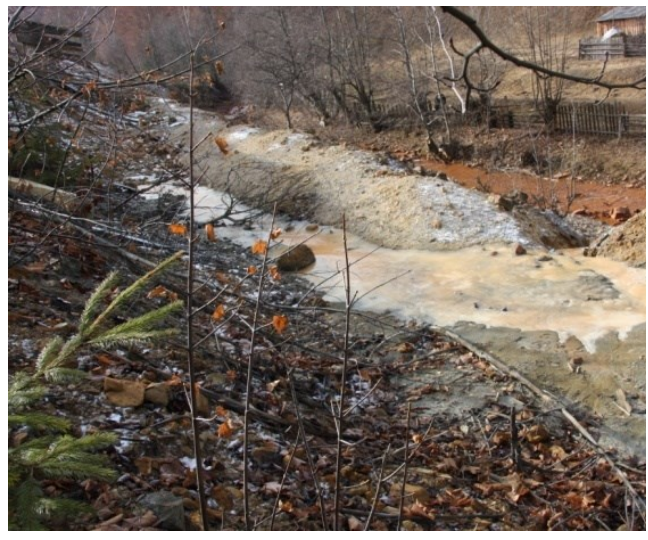

Fig.2. Sterile leakage in the micro - ponds and pyrite and zinc concentrate along the Brăteasa stream

Another important factor for the health of the local population is the quality of the air. Although the mining activity has completely ceased in 2007, emission sources of sedimentable particles from the industrial platforms from the 2 sectors of the Preparation Unit are still active. The local community of Ostra is primarily pastoral, grass vegetation being therefore extremely valuable and so particle emission can affect not only the animals through the contaminated food they eat, but also the dairy products. Forest vegetation is also affected, and since wood is one of the main income sources for the locals, the air pollution can also have effects in the local economy.

An investigation conducted for the doctoral thesis entitled "The Systemic Impact of the Useful Mineral Substance Preparation in the Suceava County” (PhD. Ing. Anca Ionce, 2010) correlated with subsequent observations has revealed the following aspects, still applicable today:

- The village Ostra is both socially and economically highly affected by the mining activity, a fact that led to uniformization of the local economy, which revolves mostly around mining- the exploitation and preparation of useful minerals was realized with a considerable population intake from outside the area, population which now adds up to the poverty rate. The opportunities after the closure of the Preparation Plant Tarnita that were supposed to be materialzed through a program of social and economic conversion according to the legislation, were never a reality. Since the area was generally perceived as unfavorable, only one investor opened a business- a sawmill and wood subassemblies factory- which is now closed. 
Of special importance for the security of the area is the stability of the tailing ponds- the closest houses being online $0.5 \mathrm{~km}$ away from the Ostra pond A,B,C. Dut to the massive tailing deposits as well as to the presence of water, any accidents can have serious consequences for the village, the transport infrastructure, the power supply, water supply etc. In case of catastrophic damage in one of the tailing ponds Tărnicioara, it is estimated that more than 120 households and economic operators will be affected, including transport infrastructure, power and water supply.

As mentioned before, the impact evaluation is made more more difficult by the fact that there is no comprehensive legislation addressing the issue.

From our correspondence with the local public administration in Ostra, in the year 2017 (which is approximately 10 years after the cessation of the activity in the Preparation Plant Tarniţa)- and from the impact studies made throughout the period of economic activity together with documentations and analyses made after the closure, we have made the following observations:

- The exploitation process of useful mineral substances together with the mecano-chemical preparation unit of complex ore and barite are pollutants with stronf impact (here we mention as very important the particle emission together with other pollutants from: ore dredging, mechanical preparation operation for copper ore and barite, calcinations, micronisation and bagging of barite concentrate, spills in the tailing ponds, sulphur oxides and hydrogen sulphide resulted from the oxidation of metal sulphides from the tailing ponds and from the ore concentrates deposites on the banks of the Brăteasa stream, spills from the former concentrator building, inadequately decommissioned);

- The most common means of economic existence for the local population are now left to be tending flocks and and the exploitation and primary preparation of wood. These are only minimal sources of income, give the precarious quality of the wood resources and of the qater quality. Although Ostra has its drinkable water levels $100 \%$ assured as a result of insfrastructure works done during the time of the mining activity and therefore has a reliable water supply network (the village has a now abandoned quarter of apartment blocks that were destined to be used by the miners), the main source of water for the domestic animals still remains the Brăteasa stream. The pollution of the stream from the former mining platforms is exacerbated by the fact that the sewage system only covers $65 \%$ of the village surface and the untreated waters end up in the stream;

- Out of the total 2000 people that were made redundant, $25 \%$ suffer from diseases typical condition associated with the mining profession: fibrosis, asthma and chronic obstructive bronchopneumopathy; 
- There are no studies regarding the level of health of the local population. Once the mining activity was ceased (the mining company is also closed down), the monitoring of the health of the population also stopped;

- The safety and ecological rehabilitation works on the four tailing ponds, though sporadic and not consistent, do not provide for jobs for the unemployed specialists. Furthermore, there is no initiative from the landowners of the affected former mining areas to inform the population downstream of the possible dangers of exposure to toxic substances.

\section{Conclusion}

We therefore conclude that the interaction between a mining operator and the human communities situated on the territory where mining activities have been or are being conducted, as long as there is an absence of an imperative legislation set to impose post-closure measures to protect the population, is in the vast majority of cases economically and socially detrimental, even hazardous, for the latter. Relying merely on the initiative of the civil society or on the company that is about to cease its activity to implement safety and decontamination measures is an unrealistic approach. Corporate ethical and socially responsible behaviour usually results from a robust legislation, from systematic pressure from the civil society or as a popularity strategy: this is not the case for most mining companies in Romania. Given the seriousness of the health and environmental impact of mining sites with ceased activity, we strongly recommend a more robust legislation that would impose such measures both throughout the mining activity and after its cessation.

\section{References}

Ionce, Anca (2009), Impactul sistemic al activităţii de preparare a substanţelor minerale utile din judeţul Suceava,,- Teză de doctorat

Mihăilă D., Budui V., Cristea I.Al., Tănasă I., (2006), Consideraţii asupra riscurilor climatice în judeţul Suceava, Analele Universitaţii „Ştefan cel Mare" Suceava, Secţiunea Geografie, Anul XV

Popa I., Barbu I., (2001), Evaluarea gradului de vătămare a ecosistemelor forestiere din zona Tarniţa prin tehnici GIS de analiză spaţială, Revista Pădurilor, Anul 116, nr. 6

*** Baza de date Agenţia pentru Protecţia Mediului Suceava

*** Baza de date Primăria comunei Ostra

*** http://unctad.org/en/docs/wir2007_en.pdf 